\title{
Efektivitas Pemberian Makanan Tambahan (PMT) Pemulihan Pada Status Gizi Balita di Wilayah Kerja Puskesmas Simomulyo, Surabaya
}

\author{
Effectiveness of Supplementary Feeding Recovery on Children Under Five \\ Nutritional Status in Simomulyo Health Center Work Area, Surabaya
}

Arum Sekar Rahayuning Putri*, Trias Mahmudiono

\begin{abstract}
ABSTRAK
Latar Belakang: Upaya yang dilakukan dalam mengatasi kekurangan gizi pada kelompok usia balita adalah program Pemberian Makanan Tambahan (PMT) Pemulihan.

Tujuan: Penelitian ini dilakukan bertujuan untuk menganalisis adanya perbedaan pada status gizi balita berasarkan BB/TB sebelum dan setelah Pemberian Makanan Tambahan (PMT) Pemulihan serta perbedaan status gizi balita setelah PMT Pemulihan dan saat sudah tidak mendapat PMT Pemulihan di wilayah kerja Puskesmas Simomulyo.

Metode: Penelitian ini adalah peneitian observasional dengan desain penelitan cross sectional. Lokasi penelitian adalah di wilayah kerja Puskemas Simomulyo, Surabaya. Sebanyak 38 balita dengan riwayat mendapat PMT Pemulihan dipilih secara acak menggunakan metode simple random sampling. Status gizi balita didapat menggunakan metode antropometri berat badan dan tinggi/panjang badan. Indeks BB/TB digunakan dalam penilaian status gizi dengan alasan sasaran utama PMT Pemulihan adalah balita dengan status gizi kurus. Uji secara statistik dilakukan menggunakan uji t berpasangan dengan tingkat signifikansi $<0,05$.

Hasil: Setelah 3 bulan mendapat PMT Pemulihan ada peningkatan persentase balita dengan status gizi normal dari $65,8 \%$ menjadi $68,4 \%$. Setelah tidak mendapat PMT Pemulihan ada penurunan persentase balita dengan status gizi normal menjadi $63,2 \%$. Tidak ada perbedaan yang bermakna status gizi balita berasarkan BB/TB sebelum dan setelah PMT Pemulihan $(p=0,585)$. Tidak ada perbedaan pada status gizi dapat disebabkan oleh konsumsi PMT yang belum optimal. Begitu juga diketahui tidak ada perbedaan yang bermakana status gizi balita setelah PMT Pemulihan dan saat sudah tidak mendapat PMT Pemulihan $(p=0,430)$.

Kesimpulan: Tidak ada perbedaan pada status gizi balita dengan indeks antropometri BB/TB saat sebelum PMT Pemulihan dan setelah PMT Pemulihan.
\end{abstract}

Kata kunci: status gizi, PMT Pemulihan, balita

\section{ABSTRACT}

Background: One of the efforts made in overcoming malnutrition in the toddler age group is by implementing a Recovery Supplementary Feeding program.

Objectives: The purpose of this study was to analyze the differences in nutritional status of children based on weight for height before and after the Supplementary Food Recovery and differences in nutritional status of children after Supplementary Food Recovery and when they had not received Supplementary Food Recovery in the Simomulyo Community Health Center work area.

Methods: This study was observational study using case-control design. A total of 38 toddlers with history of obtaining Supplemental Feeding Recovery (PMT) Program in the working area of Simomulyo Health Center were randomly selected. Nutritional status of toddlers is obtained using anthropometric methods of body weight and height / body length. Statistically tested using $t$-test paired with a significance level of $<0.05$.

Results: After not getting Supplemental Feeding Recovery, it was found that $2.6 \%$ of children under five severely wasting, $34.2 \%$ wasting, and $63.2 \%$ had normal nutritional status. There was a decrease in the percentage of infants with normal nutritional status compared to after completing PMT Recovery program from $68.4 \%$ to $63.2 \%$. There were no significant differences in nutritional status of children before and after the program ( $p=0.585)$. There was no difference between the nutritional status of children under five after the program and when they had not received the program $(p=0.430)$ 
Conclusions: There was no difference in nutritional status of children (weight-for-height) before and after Supplemental Feeding Recovery Program.

Keywords: nutritional status, Supplemental Feeding Recovery, children under five.

\author{
*Koresponden: \\ arumrahayu76@gmail.com
}

Arum Sekar Rahayuning Putri

Departemen Gizi Kesehatan, Fakultas Kesehatan Masyarakat, Universitas Airlangga Kampus C Mulyorejo, 60115 Surabaya, Jawa Timur, Indonesia

\section{PENDAHULUAN}

Status gizi adalah keluaran dari konsumsi, penyerapan, dan pemanfaatan makanan yang ditunjukkan pada keadaan tubuh ${ }^{1}$. Salah satu faktor yang memengaruhi tingkat kesehatan seseorang adalah status gizi yang baik ${ }^{2}$. Penilaian status gizi berperan untuk mengetahui ada tidaknya masalah pada status gizi seseorang, dilakukan melalui pengukuran dari beberapa parameter yang kemudian hasilnya dibandingkan dengan standard atau rujukan ${ }^{3}$. Penilaian status gizi meliputi pengukuran antropometri, pengumpulan informasi mengenai riwayat medis secara klinis dan biokimia, praktik diet, pengobatan yang dilakukan, dan situasi ketahanan pangan ${ }^{4}$.

Gizi yang cukup sangat penting pada lima tahun pertama untuk memastikan anak tumbuh dengan sehat, organ terbentuk dengan fungsi yang tepat, terbentuknya sistem kekebalan yang kuat, dan berkembangnya sistem neurologis dan kognitif ${ }^{5}$. Gizi pada masa lima tahun pertama akan mempengaruhi pertumbuhan dan perkembangan anak di masa depan ${ }^{6}$. Kekurangan gizi rawan terjadi pada kelompok usia balita sehingga perhatian perlu diberikan pada kelompok usia ini ${ }^{7}$. Dampak yang dapat timbul akibat kekurangan gizi pada lima tahun pertama adalah perkembangan otak dan pertumbuhan fisik yang terganggu sebagai dampak jangka pendek sementara dalam jangka panjang dampak yang dapat timbul adalah risiko tinggi munculnya penyakit tidak menular pada usia dewasa ${ }^{8}$. Seseorang dengan tinggi badan, berat badan, dan IMT di bawah rata-rata pada awal kehidupannya yang diikuti dengan peningkatan berat badan yang cepat pada anak-anak selanjutnya berpotensi mengalami penyakit kardiovaskular. Gangguan pertumbuhan akibat kekurangan gizi pada masa anak-anak menyebabkan overweight dan obesitas di masa dewasa dengan risiko lebih besar terkena penyakit kardiovaskular ${ }^{10,11}$.

Posisi status gizi balita di Indonesia masih termasuk dalam masalah kesehatan masyarakat apabila dlihat dari ambang batas masalah gizi. Riset Kesehatan Dasar (Riskedsdas) tahun 2018 menunjukkan secara nasional balita berat badan kurang dan sangat kurang prevalensinya adalah $17,7 \%$, balita pendek dan sangat pendek prevalensinya adalah $30,8 \%$, dan prevalensi sangat kurus dan kurus adalah 10,2\%. Pada tahun 2016 di Kota Surabaya ditemukan sebanyak 280 balita mengalami gizi buruk dan pada tahun 2017 ditemukan sebanyak 278 balita mengalami gizi buruk ${ }^{1213}$. Data BPS menunjukkan pada tahun 2016 dari 280 balita yang ditemukan mengalami gizi buruk sebanyak 35 kasus balita berada di wilayah Puskesmas Simomulyo.

Wasting atau yang selanjutnya disebut kurus adalah indikasi kekurangan gizi berdasarkan indeks $\mathrm{BB} / \mathrm{PB}$ atau BB/TB akibat dari terjadinya dalam waktu singkat sebuah peristiwa yang bersifat akut seperti kelaparan dan wabah penyakit yang mengakibatkan anak menjadi kurus ${ }^{14}$. Kurus pada anak dapat merusak fungsi sistem kekebalan tubuh, menyebabkan peningkatan pada tingkat keparahan; durasi; dan kerentanan anak terhadap penyakit menular, serta meningkatkan risiko kematian $^{15}$.

Pemberian Makanan Tambahan (PMT) Pemulihan merupakan program yang dilaksanakan pemerintah pada kelompok usia balita yang ditujukan sebagai tambahan selain makanan utama sehari-hari untuk mengatasi kekurangan gizi ${ }^{7}$. Program PMT Pemulihan ditetapkan untuk membantu memenuhi kecukupan gizi pada balita khususnya balita kurus berupa biskuit MT balita yang termasuk dalam jenis PMT pabrikan ${ }^{16}$. Biskuit PMT Pemulihan diformulasi mengandung minimum 160 kalori, 3,2-4,8 gram protein, dan 4-7,2 gram lemak tiap 40 gram biskuit. Berdasarkan petunjuk teknis pemberian makanan tambahan, sasaran utama pemberian makanan tambahan adalah balita usia 6-59 bulan dikategorikan kurus berdasarkan hasil pengukuran berat badan menurut panjang/tinggi badan ( $\mathrm{BB} / \mathrm{PB}$ atau $\mathrm{BB} / \mathrm{TB}$ ) bernilai kurang dari minus dua standar deviasi (<-2 SD) dengan lama waktu pemberian adalah 90 hari makan sesuai aturan konsumsi ${ }^{17}$.

Penelitian yang dilakukan oleh Rini, dkk di Kota Semarang mengenai perubahan status gizi balita gizi buruk setelah pemberian makanan tambahan pemulihan selama 3 bulan menunjukkan hasil bahwa ada perbedaan pada perubahan status gizi balita sebelum dan sesudah PMT Pemulihan menurut indeks antropometri $\mathrm{BB} / \mathrm{U}$. Berdasarkan indeks BB/TB menunjukkan setelah pemberian PMT Pemulihan, prevalensi balita yang sangat kurus menurun dari $100 \%$ mejadi $40,9 \%$, sedangkan berdasarkan indeks $\mathrm{BB} / \mathrm{U}$ dari $86.4 \%$ balita dengan berat badan sangat kurang menurun menjadi $59,1 \%{ }^{18}$. Penelitian lain yang dilakukan Fitriyanti dan Mulyanti mengenai PMT Pemulihan memengaruhi status gizi balita gizi buruk memberikan hasil ada perbedaan status gizi balita sebelum dan sesudah pemberian makanan tambahan pemulihan dengan nilai $p=0,001$. Perbedaan status gizi balita bendasarkan indeks antropometri BB/TB ditunjukkan dengan prevalensi balita sangat kurus yang semula $100 \%$ setelah pemberian PMT menjadi balita normal sebesar $18,2 \%$, 
balita kurus sebesar $40.9 \%$, dan balita sangat kurus $40.9 \%{ }^{19}$.

Penelitian ini dilakukan pada balita yang telah mengikuti program PMT Pemulihan di tahun 2018 di wilayah kerja Puskesmas Simomulyo. PMT yang diterima oleh balita berupa biskuit sebanyak 90 hari makan. Peneliti melakukan studi pendahuluan sebelumnya di Puskesmas Simomulyo untuk mengetahui pelaksanaan program Pemberian Makanan Tambahan (PMT) Pemulihan di tahun 2018 meliputi jumlah balita yang berpartisipasi, status gizi balita sebelum mendapatkan PMT Pemulihan dan status gizi balita tiga bulan setelah mendapat PMT Pemulihan. Hasil menunjukkan dari 69 balita yang berpartisipasi sebesar $58 \%$ dari jumlah peserta mengalami peningkatan pada nilai $z$-score berdasarkan BB/TB dan sisanya tidak mengalami peningkatan. Menindaklanjuti hasil dari program PMT Pemulihan yang diadakan Puskesmas Simomulyo, peneliti ingin mengetahui gizi balita setelah program PMT Pemulihan.

Berdasarkan uraian masalah, penelitian ini bertujuan untuk menganalisis perbedaan status gizi balita sebelum dan setelah Pemberian Makanan Tambahan (PMT) Pemulihan serta perbedaan status gizi balita setelah PMT Pemulihan dan saat sudah tidak mendapat PMT Pemulihan di wilayah kerja Puskesmas Simomulyo.

\section{METODE}

Merupakan penelitian observasional dengan desain penelitian cross sectional. Lokasi dilaksanakannya penelitian adalah di wilayah kerja Puskesmas Simomulyo, Kota Surabaya. Penelitian dilaksanakan pada bulan Januari-Februari 2019, atau setelah 5 bulan selesai program PMT Pemulihan. Pada penelitian ini populasi yang digunakan adalah seluruh balita di wilayah kerja Puskesmas Simomulyo yang telah mendapat PMT Pemulihan di tahun 2018. Sampel pada penelitian ini adalah 38 balita dari keseluruhan populasi yang telah memenuhi kriteria inklusi penelitian. Teknik simple random sampling digunakan dalam melakukan pemilihan sampel. Kriteria inklusi penelitian ini adalah balita yang telah mendapat PMT Pemulihan di tahun 2018, balita tidak memiliki riwayat kelainan bawaan berat, dan balita tidak memiliki riwayat lahir kurang bulan. Kriteria eksklusi pada penelitian ini adalah balita yang drop out dari program PMT Pemulihan. Indeks BB/TB digunakan sebagai perbandingan karena berdasarkan petunjuk teknis pemberian makanan tambahan sasaran utama PMT Pemulihan balita adalah balita kurus.

Sebelum program PMT Pemulihan dilaksanakan, Puskesmas Simomulyo melakukan seleksi terlebih dahulu terhadap balita-balita yang akan mengikuti program tersebut. Balita yang dipilih untuk mengikuti program PMT Pemulihan ditentukan melalui data hasil penimbangan dan pengukuran bulanan. Balita yang dipilih mengikuti program PMT Pemulihan adalah balita dengan status gizi berdasarkan pengukuran antropometri dengan indeks BB/TB termasuk dalam kategori kurus dan sangat kurus, selain itu balita yang berat badannya termasuk dalam bawah garis merah
(BGM) serta balita dengan berat badan tidak mengalami pengingkatan (2T) juga dipilih untuk mengikuti program PMT Pemulihan. Makanan tambahan yang diberikan mengandung formulasi khusus dengan tambahan fortifikasi vitamin dan mineral berupa biskuit.

Karakteristik responden dikumpulkan melalui metode wawancara menggunakan kuesioner meliputi data karakteristik balita seperti usia dan jenis kelamin balita, serta karakteristik keluarga seperti pendidikan ayah, pendidikan ibu, pekerjaan ayah, dan pekerjaan ibu. Penilaian konsumsi PMT Pemulihan tidak dilakukan secara kuantitatif karena tidak terdapat catatan mengenai jumlah konsumsi PMT Pemulihan balita sehingga hanya diberi pertanyaan balita mengonsumsi habis atau tidak habis PMT Pemulihan.

Metode antropometri digunakan dalam melakukan penilaian status gizi balita. Status gizi balita ditentukan menggunakan antropometri dengan parameter berat badan dan panjang/tinggi badan. Hasil pengukuran yang didapatkan kemudian dihitung $z$-score dengan indeks BB/TB menggunakan aplikasi Emergency Nutrition Assessment (ENA) for SMART dengan pengaturan WHO standards 2006. Pengukuran berat badan balita dilakukan menggunakan timbangan digital sementara pengukuran tinggi badan balita dilakukan menggunakan microtoise.

Uji paired t-test digunakan untuk membandingkan status gizi balita sebelum dan setelah Pemberian Makanan Tambahan (PMT) Pemulihan dan membandingkan status gizi balita setelah PMT Pemulihan dan saat sudah tidak mendapat PMT Pemulihan pada dua kelompok.

Penelitian telah memperoleh persetujuan dari Komisi Etik Penelitian Fakultas Kesehatan MasyarakatUniversitas Airlangga dengan nomor: 569/EA/KEPK/2018. Sementara persetujuan mengikuti penelitian diperoleh melalui Inform consent yang ditandatangani oleh ibu atau keluarga balita.

\section{HASIL DAN PEMBAHASAN}

Distribusi karakteristik responden meliputi karakteristik balita yaitu usia, jenis kelamin, riwayat $B B L R$, riwayat ASI eksklusif, kejadian diare, dan konsumsi PMT serta karakteristik keluarga yaitu pendidikan ayah, pendidikan ibu, pekerjaan ayah, dan pekerjaan ibu tersaji pada tabel 1. Pada penelitian ini jenis kelamin balita sebagian besar adalah perempuan yaitu $65,8 \%$. Kebutuhan gizi seseorang, besar kecilnya salah satunya ditentukan oleh jenis kelamin, anak lelaki lebih banyak membutuhkan energi dan protein dibandingkan anak perempuan ${ }^{1}$. Usia balita sebagian besar berkisar antara 37-59 bulan sebesar $57.9 \%$. Usia balita merupakan masa dimana pertumbuhan dan perkembangan berjalan cepat, mulai terpapar infeksi, dan aktif secar fisik sehingga harus terpenuhi kebutuhannya akan zat gizi dengan mempertimbangkan aktivitas dan keadaan infeksi ${ }^{20}$. Bertambahnya usia berbanding lurus dengan peningkatan jumlah kebutuhan zat gizi ${ }^{21}$. Sebesar $73,7 \%$ balita tidak mengonsumsi habis PMT yang diberikan, ketika ditanya alasan tidak mengonsumsi habis sebagian 
menjawab balita kurang menyukai rasa PMT yang diberikan karena membuat enek sebagian lain menjawab balita bosan mengonsumsi PMT yang diberikan.

Sebagian besar ayah balita memiliki jenjang pendidikan tamat SMA yaitu $65,8 \%$. Begitu pula dengan ibu balita, sebesar $60,5 \%$ ibu balita memiliki jenjang pendidikan tamat SMA. Sebesar $50 \%$ ayah balita memiliki pekerjaan sebagai pegawai swasta. Sementara itu sebagian besar ibu balita tidak bekerja. Tingkat pendidikan dan pekerjaan orang tua disebut sebagai faktor eksternal yang memengaruhi gizi balita ${ }^{26}$. Pendidikan yang baik pada orangtua membuat mereka dapat menerima segala informasi terutama pengasuhan anak dengan cara yang baik sehingga pendidikan orang tua menjadi salah satu faktor penting dalam tumbuh kembang anak ${ }^{27}$.

Tabel 1. Distribusi Karakteristik Balita di Wilayah Kerja Puskesmas Simomulyo Surabaya Tahun 2019

\begin{tabular}{|c|c|c|}
\hline Karakteristik & $\mathrm{n}$ & $\%$ \\
\hline \multicolumn{3}{|l|}{ Pendidikan Ayah } \\
\hline Tidak tamat SD & 0 & 0 \\
\hline Tamat SD & 6 & 15,8 \\
\hline Tamat SMP & 5 & 13,2 \\
\hline Tamat SMA & 25 & 65,8 \\
\hline Tamat Perguruan Tinggi & 2 & 5,3 \\
\hline \multicolumn{3}{|l|}{ Pendidikan Ibu } \\
\hline Tidak tamat SD & 2 & 5,3 \\
\hline Tamat SD & 5 & 13,2 \\
\hline Tamat SMP & 8 & 21,1 \\
\hline Tamat SMA & 23 & 60,5 \\
\hline Tamat Perguruan Tinggi & 0 & 0 \\
\hline \multicolumn{3}{|l|}{ Pekerjaan Ayah } \\
\hline Tidak bekerja & 2 & 5,3 \\
\hline Pegawai Swasta & 19 & 50 \\
\hline Wiraswasta & 3 & 7,9 \\
\hline Buruh & 14 & 36,8 \\
\hline \multicolumn{3}{|l|}{ Pekerjaan Ibu } \\
\hline Tidak bekerja & 32 & 84,2 \\
\hline Pegawai Swasta & 2 & 5,3 \\
\hline Wiraswasta & 1 & 2,6 \\
\hline Buruh & 3 & 7,9 \\
\hline \multicolumn{3}{|l|}{ Jenis Kelamin Balita } \\
\hline Laki-laki & 13 & 34,2 \\
\hline Perempuan & 25 & 65,8 \\
\hline \multicolumn{3}{|l|}{ Usia Balita (Bulan) } \\
\hline $12-36$ & 16 & 42.1 \\
\hline $37-59$ & 22 & 57.9 \\
\hline \multicolumn{3}{|l|}{ Konsumsi PMT } \\
\hline Ya (biskuit dikonsumsi habis oleh balita) & 9 & 23,7 \\
\hline Tidak (biskuit tidak dikonsumsi habis oleh balita) & 29 & 76,3 \\
\hline
\end{tabular}

Data mengenai status gizi balita tersaji pada tabel 2. Tabel memuat status gizi balita sebelum pelaksanaan program PMT Pemulihan, status gizi balita setelah 3 bulan PMT Pemulihan, dan status gizi balita saat penelitian. Selain tersaji dalam tabel, persentase status gizi balita juga tersaji dalam grafik 1 . Sebelum pelaksanaan penelitian diketahui sebesar $34,2 \%$ memiliki status gizi kurus dan $65,8 \%$ memiliki status gizi normal.
Setelah 3 bulan pelaksanaan, hasil penimbangan dan pengukuran menunjukkan sebesar $31,6 \%$ balita memiliki status gizi kurus dan $68,4 \%$ memiliki status gizi normal. Kemudian, saat penelitian dilakukan penimbangan dan pengukuran pada balita responden, sebesar $2,6 \%$ balita memiliki status gizi sangat kurus, $34,2 \%$ balita memiliki status gizi kurus, dan $63,2 \%$ memiliki status gizi normal.

Tabel 2. Distribusi Status Gizi Balita di Wilayah Kerja Puskesmas Simomulyo Tahun 2018

\begin{tabular}{lcccccc}
\hline \multirow{2}{*}{ Status Gizi } & \multicolumn{2}{c}{ Sebelum PMT Pemulihan } & \multicolumn{2}{c}{ Setelah PMT Pemulihan } & \multicolumn{2}{c}{ Saat Penelitian } \\
\cline { 2 - 7 } & $\mathbf{n}$ & $\mathbf{\%}$ & $\mathbf{n}$ & $\mathbf{\%}$ & $\mathbf{n}$ & $\mathbf{\%}$ \\
\hline <-3SD (Sangat Kurus) & 0 & 0 & 0 & 0 & 1 & 2,6 \\
-3SD s/d -2SD (Kurus) & 13 & 34,2 & 12 & 31,6 & 13 & 34,2 \\
-2SD s/d +2SD (Normal) & 25 & 65,8 & 26 & 68,4 & 24 & 63,2 \\
\hline Total & 38 & 100,0 & 38 & 100,0 & 38 & 100,0 \\
\hline
\end{tabular}




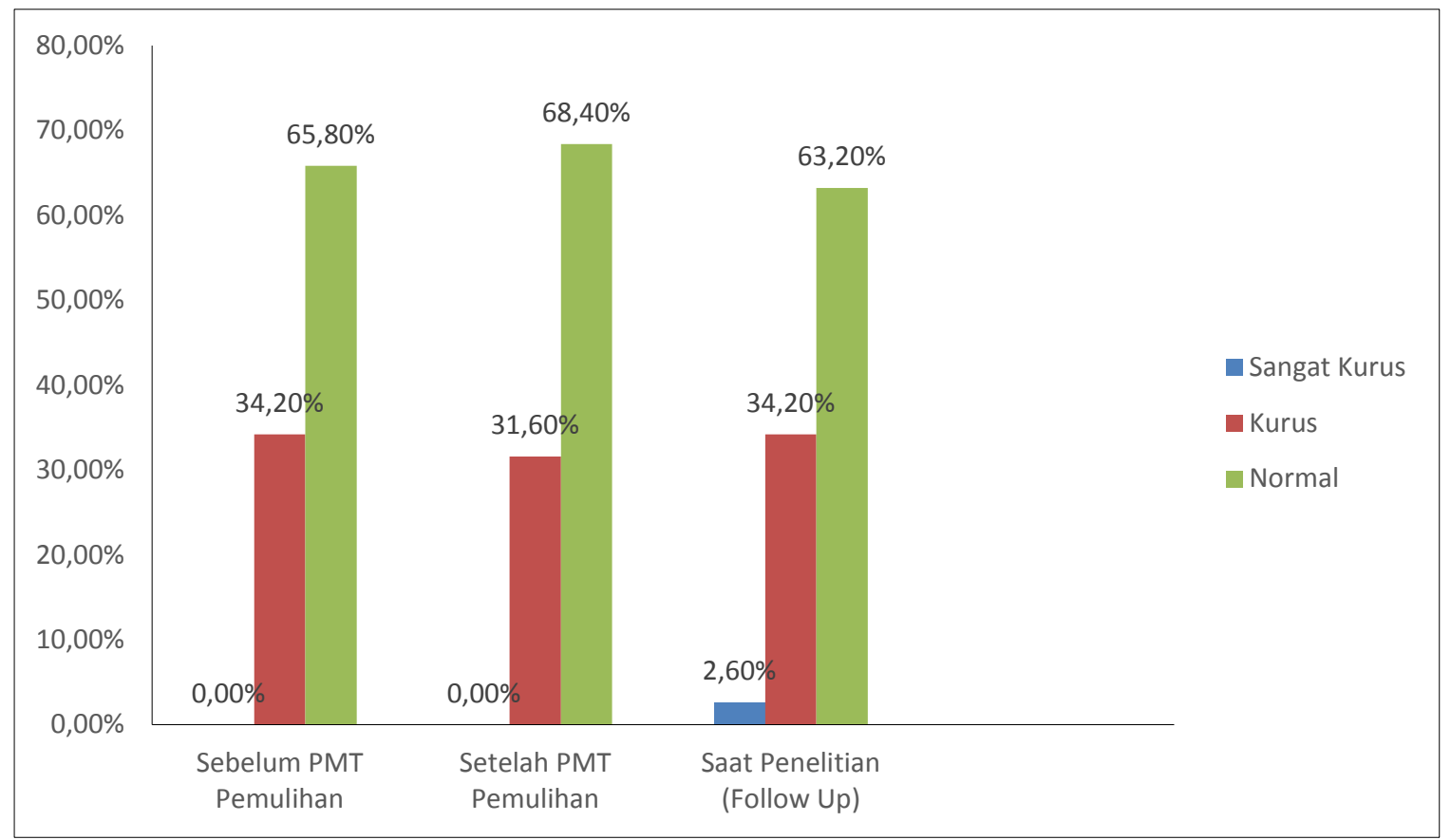

Grafik 1. Persentase Perubahan Status Gizi Balita

Tabel 3 menunjukkan rata-rata $z$-score balita sebelum PMT Pemulihan adalah -1.47 dengan $z$-score minimum -2.96 dan maksimum 0.49. Kemudian setelah 3 bulan pelaksanaan PMT Pemulihan didapatkan rata-rata $z$-score balita adalah-1.45 dengan z-score minimum -2.81 dan maksimum 0.62. Selanjutnya, saat penelitian didapatkan rata-rata $z$-score balita adalah -1.58 dengan z-score minimum -3.36 dan maksimum 0.29. Uji statistik dua sampel berpasangan menunjukkan bahwa tidak ada perbedaan yang bermakna pada status gizi balita indeks BB/TB sebelum program PMT Pemulihan dan setelah program PMT Pemulihan yang ditunjukkan dengan nilai $p=0,585(p>0,05)$.

Penelitian di Kota Semarang memberikan hasil yang serupa bahwa tidak terdapat perbedaan yang bermakna pada perubahan rerata nilai Z-score indeks antropometri $\mathrm{BB} / \mathrm{TB}$ sebelum dan sesudah PMT Pemulihan sementara pada indeks antropometri $B B / U$ terdapat perbedaan yang bermakna pada perubahan rerata nilai $z$-score, hal ini dapat disebabkan oleh indeks antropometri $\mathrm{BB} / \mathrm{U}$ cenderung lebih sensitif terhadap perubahan-perubahan kecil yang mendadak dan mempengaruhi pengukuran berat badan sedangkan tinggi badan memiliki tingkat sensitifitas lebih rendah terhadap defisiensi gizi dalam jangka waktu pendek ${ }^{18}$. Hasil yang serupa juga ditunjukkan oleh penelitian yang dilakukan di Puskesmas Sukatani dan Puskesmas Pasirukem, Kabupaten Karawang. Pemberian Makanan Tambahan berupa susu dan biskuit yang berlangsung selama tiga bulan tidak efektif dalam meningkatkan status gizi balita berdasarkan indikator $\mathrm{BB} / \mathrm{TB}^{28}$.

Hasil penelitian ini bertentangan dengan penelitian di Semarang yang menyebutkan bahwa setelah pemberian makanan tambahan pemulihan selama 60 hari ditemukan adanya perbedaan status gizi berdasarkan BB/TB disebabkan oleh kontribusi asupan energi dan protein dari PMT Pemulihan yang diasup oleh balita mengalami peningkatan setiap minggunya ${ }^{19}$. Penelitian yang dilakukan di Banyumas dan Kediri menunjukkan hasil bahwa ada perbedaan pada berat badan balita sebelum dan setelah PMT Pemulihan yang berarti PMT Pemulihan efektif terhadap perubahan berat badan balita ${ }^{2930}$. Peningkatan derajat kesehatan anak dapat dipengaruhi oleh pemberian PMT yang berkualitas secara terus menerus yang kandungannya mampu membantu mencukupi kebutuhan gizi ${ }^{31}$.

Tabel 3. Perbedaan Status Gizi Indeks BB/TB Balita Sebelum PMT Pemulihan-Setelah PMT Pemulihan dan Setelah PMT Pemulihan-Saat Penelitian di Wilayah Kerja Puskesmas Simomulyo Tahun 2018

\begin{tabular}{|c|c|c|c|c|c|}
\hline \multirow{2}{*}{ Penilaian Status Gizi (z-score) } & \multirow{2}{*}{ Mean } & \multirow{2}{*}{ SD } & \multicolumn{2}{|c|}{$95 \% \mathrm{Cl}$} & \multirow{2}{*}{$p$ value* } \\
\hline & & & Lower & Upper & \\
\hline Sebelum PMT Pemulihan & $-1,47$ & 0,87 & $-2,96$ & 0,49 & \multirow{2}{*}{0,585} \\
\hline Setelah PMT Pemulihan & $-1,45$ & 0,86 & $-2,81$ & 0,62 & \\
\hline Setelah PMT Pemulihan & $-1,45$ & 0,86 & $-2,81$ & 0,62 & \multirow{2}{*}{0,430} \\
\hline Saat Penelitian & $-1,58$ & 0,90 & $-3,36$ & 0,29 & \\
\hline
\end{tabular}

Perubahan status gizi balita dapat disebabkan oleh kepatuhan konsumsi biskuit PMT Pemulihan. Pada penelitian ini sebagian besar balita belum mengonsumsi biskuit PMT Pemulihan secara optimal (23,7\%).
Pemberian makanan tambahan pemulihan mengandung zat gizi yang dapat membantu menambah pemenuhan asupan balita sehingga tingkat asupan dalam sehari sebagian besar dapat terpenuhi ${ }^{1932}$. Konsumsi biskuit 
secara patuh membantu memenuhi kecukupan asupan diiringi dengan konsumsi pangan yang cukup, asupan yang cukup dapat menyebabkan peningkatan pada status gizi $^{33}$. Konsumsi PMT Pemulihan dapat membantu memenuhi kebutuhan energi dan protein balita yang mengalami kekurangan gizi sehingga apabila diberikan secara tepat maka dapat menyebabkan status gizi menjadi lebih baik ${ }^{34}$. Pada penelitian pemberian biskuit yang diperkaya protein tepung lele dumbo di Sukabumi diketahui bahwa tingkat kepatuhan konsumsi biskuit dengan status gizi juga menunjukkan ada hubungan signifikan $^{33}$.

Hasil uji t dua sampel berpasangan menunjukkan tidak terdapat perbedaan yang bermakna pada status gizi balita indeks BB/TB setelah PMT Pemulihan dan saat penelitian yang ditunjukkan dengan nilai $p=0.430$ ( $p>0,05)$. Data yang didapat menunjukkan bahwa setelah 5 bulan selesai PMT Pemulihan ada penurunan persentase balita dengan status gizi normal dari $68,4 \%$ menjadi $63,2 \%$ dan ditemukan balita dengan status gizi sangat kurus sebesar $2,6 \%$. Selain itu diketahui ada penurunan rata-rata $z$-score balita saat penelitian dengan setelah 3 bulan PMT Pemulihan sebesar 0.13.

Penelitian ini menganalisis perbedaan status gizi balita selama mendapat PMT Pemulihan dan setelah tidak mendapat PMT Pemulihan, namun peneliti tidak meneliti variable lain seperti hubungan konsumsi PMT Pemulihan dengan status gizi. Pada penelitian ini penilaian konsumsi PMT Pemulihan tidak dapat dilakukan secara kuantitatif dikarenakan tidak ada catatan jumlah konsumsi biskuit PMT Pemulihan balita.

Pemberian makanan tambahan merupakan salah satu strategi suplementasi dalam mengatasi masalah gizi. Pemberian makanan tambahan bertujuan untuk meningkatkan asupan gizi yang akhirnya dapat meningkatkan status gizi sasaran ${ }^{17}$. Pada penelitian ini diketahui tidak ada perbedaan antara status gizi sebelum penelitian dan setelah penelitian, meskipun begitu ada peningkatan pada rata-rata $z$-score balita setelah PMT Pemulihan. Tidak ada perbedaan antara status gizi balita setelah PMT Pemulihan dan saat penelitian, selain itu diketahui ada penurunan pada rata-rata $z$-score balita saat penelitian. Perlu dilakukan evaluasi lebih lanjut mengenai pemberian makanan tambahan khususnya analisis terkait penurunan status gizi setelah tidak mendapat PMT Pemulihan.

\section{KESIMPULAN}

Hasil penelitian menunjukkan bahwa tidak ada perbedaan pada status gizi balita sebelum pelaksanaan program PMT Pemulihan dan setelah pelaksanaan PMT Pemulihan. Selain itu tidak ada perbedaan antara status gizi balita setelah pelaksanaan PMT Pemulihan dengan saat penelitian, diketahui adanya penurunan persentase balita dengan status gizi normal saat penelitian. Peneliti merekomendasikan pada peneliti yang ingin melakukan penelitian lebih lanjut untuk mencari faktor-faktor yang menyebabkan penurunan status gizi balita setelah tidak mendapat PMT Pemulihan.

\section{ACKNOWLEDGEMENT}

Peneliti mengucapkan terimakasih kepada ibu balita, para kader posyandu balita yang terlibat, koordinator kader, dan Puskesmas Simomulyo atas bantuan dan partisipasinya dalam perjalanan penelitian. Ucapan terima kasih juga diberikan kepada dosen pembimbing atas arahan dan bimbingan yang telah diberikan.

\section{REFERENS}

1. Adriani, M. \& Wijatmadi, B. Gizi dan Kesehatan Balita Peranan Mikro Zinc pada Pertumbuhan Balita. (Kencana Prenada Media Grup, 2014).

2. Kementerian Kesehatan RI. Warta Kesmas 'Gizi, Investasi Masa Depan Bangsa'. 2, (2017).

3. Par'i, H. M., Wiyono, S. \& Harjatmo, T. P. Bahan Ajar Gizi 'Penilaian Status Gizi'. (Badan Pengembangan dan Pemberdayaan Sumber Daya Manusia Kesehatan, 2017).

4. NACS. MODULE 2. Nutrition Assessment and Classification. Nutr. Assessment, Couns. Support (2016).

5. Unicef, World Health Organization \& The World Bank. Joint Child Malnutrition Estimates: Levels and Trends in Child Malnutrition. 35 (2012) doi:10.1093/ije/dyr050.

6. Pusat Data dan Informasi Kementerian Kesehatan RI. Situasi Gizi di Indonesia. (2016).

7. Kementerian Kesehatan RI. Panduan Penyelenggaraan Pemberian Makanan Tambahan Pemulihan Bagi Balita Gizi Kurang (Bantuan Operasional Kesehatan). Ditjen Bina Gizi dan Kesehat. Ibu dan Anak Kementeri. Kesehat. RI 1-40 (2011) doi:10.1017/СBO9781107415324.004.

8. Republik Indonesia. Pedoman Perencanaan Program Gerakan Nasional Percepatan Perbaikan Gizi Dalam Rangka Seribu Hari Pertama Kehidupan. (2013).

9. Kementerian Sosial RI. Modul Kesehatan dan Gizi. Progr. Kel. Harapan Kementeri. Sos. RI 1117 (2018).

10. DeBoer, M. D. et al. Early Childhood Growth Failure and The Developmental Origins of Adult Disease: Do Enteric Infections and Malnutrition Increase Risk for The Metabolic Syndrome? Nutr. Rev. 70, 642-653 (2012).

11. Hoddinott, J. et al. Adult Consequences of Growth Failure in Early Childhood. Am. J. Clin. Nutr. 98, 1170-1178 (2013).

12. Kementerian Kesehatan RI. Profil Kesehatan Provinsi Jawa Timur Tahun 2016. (2017).

13. Badan Pusat Statistik Provinsi Jawa Timur. Provinsi Jawa Timur Dalam Angka 2018. (2017).

14. Balitbangkes. Riset Kesehatan Dasar 2013 (2013) doi:1 Desember 2013.

15. World Health Organization. Country Profile Indicators 'Interpretation Guide'. Nutr. Landacape Inf. Syst. 1-51 (2010) doi:10.1159/000362780.Interpretation. 
16. Pusat Data dan Informasi Kementerian Kesehatan RI. Situasi Balita Pendek (Stunting) di Indonesia. Jendela Data dan Inf. Kesehat. 1, 2 (2018).

17. Kementerian Kesehatan RI. Petunjuk Teknis Pemberian Makanan Tambahan (Balita - Anak Sekolah - Ibu Hamil). (2017).

18. Rini, I., Pangestuti, R. D. \& Rahfiludin, M. . Z. Pengaruh Pemberian Makanan Tambahan Pemulihan (PMT-P) Terhadap Perubahan Status Gizi Balita Gizi Buruk Tahun 2017 (Studi di Rumah Gizi Kota Semarang). J. Kesehat. Masy. 5, 698-705 (2017).

19. Fitriyanti, F. \& Mulyati, T. Pengaruh Pemberian Makanan Tambahan Pemulihan (PMT-P) Terhadap Status Gizi Buruk di Dinas Kesehatan Kota Semarang Tahun 2012. J. Nutr. Coll. 1, 373-381 (2014).

20. Kementerian Kesehatan RI. Pedoman Gizi Seimbang. Riskesdas 99 (2014).

21. Arifin, Z. Gambaran Pola Makan Anak Usia 3-5 Tahun Dengan Gizi Kurang Di Pondok Bersalin Tri Sakti Balong Tani Kecamatan Jabon-Sidoarjo. Midwiferia 1, 16 (2015).

22. Kementerian Kesehatan RI. Profil Kesehatan Indonesia 2014. Kementerian Kesehatan Republik Indonesia vol. 51 (2015).

23. Wardani, M. S. Faktor-Faktor Yang Mempengaruhi Status Gizi Balita Di RW 06 Kelurahan Pancoran Mas Kecamatan Pancoran Mas - Depok. (2012).

24. Patimah, S. Gizi Remaja Putri Plus 1000 Hari Pertama Kehidupan. (PT Refika Aditama, 2017).

25. Kementerian Kesehatan RI. Situasi Diare di Indonesia. Bul. Jendela Data dan Inf. Kesehat. 2, 1-44 (2011).

26. Adriani, M. \& Wijatmadi, B. Peranan Gizi dalam Siklus Kehidupan. (Kencana Prenada Media Grup, 2014).

27. Wati, S. P. Hubungan Tingkat Pendidikan, Pengetahuan Ibu dan Pendapatan Orangtua dengan Status Gizi Anak Balita Usia 1-5 tahun di
Desa Duwet Kecamatan Wonosari Kabupaten Klaten. (Universitas Muhammadiyah Surakarta, 2018).

28. Nurina, R. Program Pemberian Makanan Tambahan untuk Peningkatan Status Gizi Ibu Hamil dan Balita di Kecamatan Cilamaya Kulon dan Cilamaya Wetan, Karawang. J. CARE 1, 4449 (2016).

29. Ersa, A., Artathi Eka, S. \& Walin. Efektivitas Program PMT Pemulihan Terhadap Kenaikan Berat Badan Pada Balita Status Gizi Buruk di Kabupaten Banyumas. J. IIm. Kebidanan 4, 220226 (2013).

30. Anggraeni, S. \& Hari Poernomo, D. Pengaruh Pemberian Makanan Tambahan Pemulihan (PMT-P) Terhadap Pertumbuhan Balita Bawah Garis Merah (BGM) di Puskesmas Kota Wilayah Selatan Kediri. J. Penelit. STIKES Kediri 4, 1-7-7 (2011).

31. Retnowati, D. H., Syamsianah, A. \& Handarsari, E. Pengaruh Pemberian Makanan Tambahan Pemulihan Terhadap Perubahan Berat Badan Balita Bawah Garis Merah Kecacingan Di Wilayah Puskesmas Klambu Kabupaten Grobogan. J. Gizi Univ. Muhammadiyah Semarang 4, 30-36 (2015).

32. Puspita Febrindari, A. \& Nuryanto. Hubungan Asupan Energi, Protein, Seng, Dan Kejadian Infeksi Kecacingan Status Gizi Anak Umur 12-36 Bulan. J. Nutr. Coll. 5, 353 (2016).

33. Hidayati, B. S. Hubungan Kepatuhan Konsumsi Biskuit yang Diperkaya Protein Tepung Ikan Lele Dumbo (Clarias gariepinus) dengan Status Gizi dan Morbiditas Balita di Warungkiara, Bantargadung, Kabupaten Sukabumi. http://repository.ipb.ac.id/handle/123456789/5 3464 (2011).

34. Adelasanti, A. N. \& Rakhma, L. R. Hubungan Antara Kepatuhan Konsumsi Pemberian Makanan Tambahan Balita dengan Perubahan Status Gizi Balita di Puskesmas Pucangsawit Surakarta. J. Dunia Gizi 1, 92-100 (2018). 